\title{
Dairy science and health in the tropics: challenges and opportunities for the next decades
}

\author{
Lorenzo E. Hernández-Castellano ${ }^{1} \cdot$ Jarlath E. Nally ${ }^{2} \cdot$ Johanna Lindahl $^{3} \cdot$ Metha Wanapat $^{4} \cdot$ Ibrahim A. Alhidary ${ }^{5}$. \\ David Fangueiro $^{6}$ - Delia Grace ${ }^{3} \cdot$ Marcelo Ratto $^{7}$. Jean Christophe Bambou ${ }^{8}$ - André M. de Almeida ${ }^{6}$
}

Published online: 26 March 2019

(C) Springer Nature B.V. 2019

\begin{abstract}
In the next two decades, the world population will increase significantly; the majority in the developing countries located in the tropics of Africa, Asia, Latin America, and the Caribbean. To feed such a population, it is necessary to increase the availability of food, particularly high-value animal protein foods produced locally, namely meat and dairy products. Dairy production in tropical regions has a lot of growth potential, but also poses a series of problems, particularly as dairy production systems were developed in temperate countries and in most cases are difficult to implement in the tropics. Drawbacks include hot weather and heat stress, the lack of availability of adequate feeds, poor infrastructure, and cold chain and the competition with cheap imports from temperate countries. This position paper reviews the major drawbacks in dairy production for the five major dairy species: cattle, water buffalo, sheep, goat, and camel, as well as the future trends in research and development. It also concerns the major trends in reproduction and production systems and health issues as well as environmental concerns, particularly those related to greenhouse gas emissions. Tropical Animal Health and Production now launches a topical collection on Tropical Dairy Science. We aim to publish interesting and significant papers in tropical dairy science. On behalf of the editorial board of the Tropical Animal Health and Production, we would like to invite all authors working in this field to submit their works on this topic to this topical collection in our journal.
\end{abstract}

\section{Introduction}

Milk and dairy products are one of the most important sources of animal protein for human diets worldwide. Indeed, milk is produced and consumed fresh or processed in almost every country in the world. Raw milk may be transformed into a vast array of products. These include for instance cheese, butter, yoghurt, or kefir. According to the FAO (Food and Agricultural Organization of the United Nations, http://www.

This article belongs to the Topical Collection: Dairy Science and Health in the Tropics

André M. de Almeida

aalmeida@isa.ulisboa.pt

1 Department of Animal Science, AU-Foulum, Aarhus University, 8830 Tjele, Denmark

2 Infectious Bacterial Diseases Research Unit, National Animal Disease Center, Agricultural Research Service, United States Department of Agriculture, Ames, IA, USA

3 ILRI - International Livestock Research Institute, SE Asia Branch, Hanoi, Vietnam fao.org/faostat/en), almost 800 billion tons of milk was produced in 2016, being $82.5 \%$ produced by cows and 13 . $9 \%$ by water buffalo. Other dairy species such as sheep, goats, and dromedaries yield roughly $4 \%$ of the milk produce worldwide.

Dairy production is a key element of agriculture in the tropics and the subtropics. As depicted in Fig. 1, very different systems from small-scale subsistence farming to high-tech dairy farms exist in these areas. Nevertheless, these vast

4 Tropical Feed Resources Research and Development Center (TROFREC), Faculty of Agriculture, Khon Kaen University, Khon Kaen 40002, Thailand

5 King Saud University, Riyadh, Saudi Arabia

6 LEAF, Instituto Superior de Agronomia, Universidade de Lisboa, Tapada da Ajuda, 1349-017 Lisbon, Portugal

7 Department of Animal Science, Universidad Austral de Chile, Valdivia, Chile

8 INRA - Unité de Recherches Zootechniques, Domaine de Duclos, Prise d'eau, Guadeloupe 

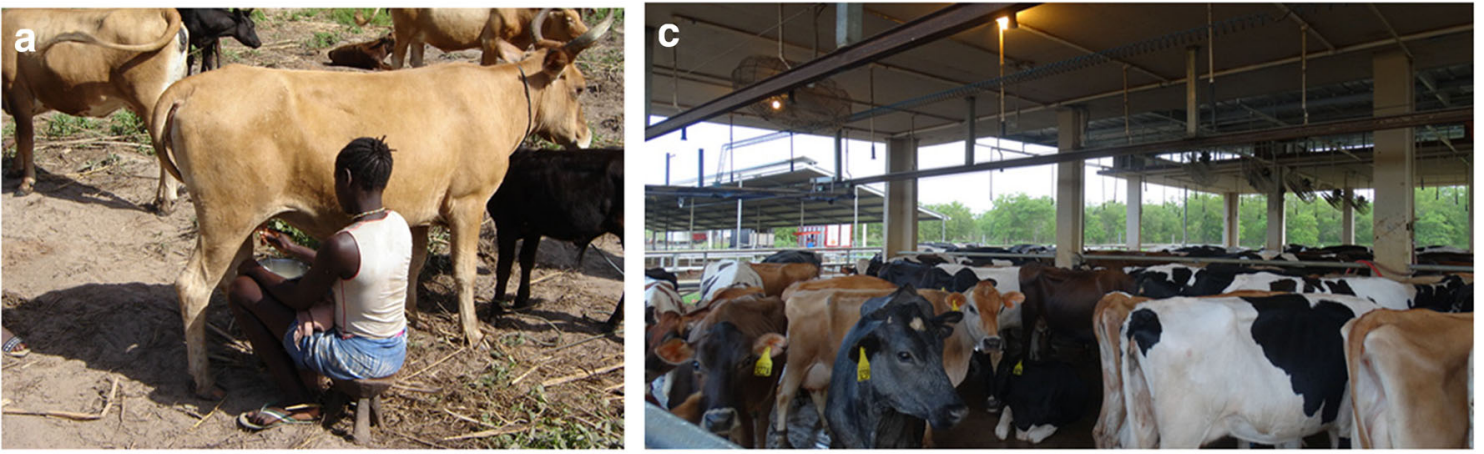

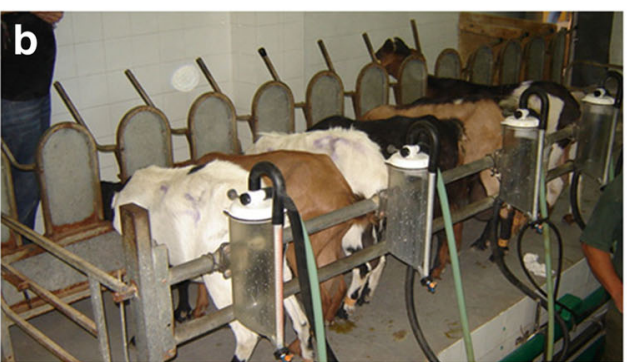

Fig. 1 Contrasting dairy production systems in tropical regions. a Hand milking of an N'Dama cow in the Cacheu Region in Northern GuineaBissau, West Africa. b Intensive goat milk production in the subtropical archipelago of the Canary Islands (Spain). c High-production dairy farm using Holstein and Jersey genotypes in the island of Puerto Rico in the

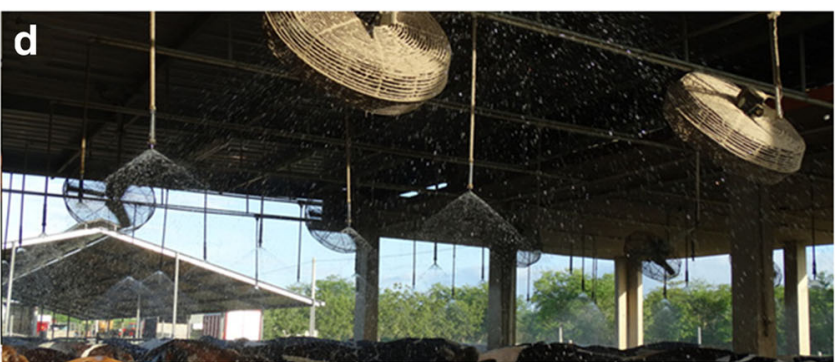

Caribbean. d Cooling devices used to reduce heat stress in an intensive dairy farm on the island of Puerto Rico in the Caribbean. All photos by AM Almeida with the exception of $\mathbf{c}$ and $\mathbf{d}$, courtesy of Prof. Guillermo Ortiz-Colon (University of Puerto Rico)

the temperate world, where most of the dairy research is centered and focused.

To inaugurate this collection, the Tropical Animal Health and Production Editorial Board has decided to write a position and opinion paper on this area, specifically focused on the problems that will be necessary to solve in the near future. This article includes sections on the different dairy species: bovine, water buffalo, small ruminants, and camels. It includes also specific sections on areas that are essential for a stable and productive dairy sector: reproduction, production systems, epidemiology, and health. We finally conclude with a section on a relatively novel but extremely important concern: the environmental costs of dairy production.

On behalf of the editorial board of Tropical Animal Health and Production, we would like to invite all authors working in this field to consider submitting their works on this fascinating topic to this topical collection in our journal.

\section{Dairy cattle production in the tropics: a preponderant role for physiology}

In the last century, dairy production strategies were based on increased milk productions. However, these strategies have been changing over the years and nowadays they focus not only on productivity and but also on efficient and sustainable milk production. Therefore, the old-fashion question of "how much milk is produced" has been replaced by "how milk is 
produced." This new question involves aspects such as the use of more sustainable feed resources, animal health and welfare, milk quality, and the impact of animal production activities on the environment. In the next 50 years, dairy producers in the tropics will need to deal with the above-mentioned aspects in a world where the population will continuously grow, arable land will decrease, and climate conditions will be more adverse for both crops and dairy cows (Britt et al. 2018). Therefore, the selection and use of dairy breeds adaptable to specific tropical regions and improvements in quality and digestibility of diverse crops tolerant to droughts and high temperatures will be essential in the coming years for dairy production in the tropics. Selection for environmental-related traits will contribute for instance to select cows based on methane emissions, tolerance for heat stress, and/or adaptability to the seasonal scarcity of pasture. On the other hand, selection for health-related traits will contribute to breeding cows more tolerant of metabolic diseases and with an improved immune condition. These traits will be of special interest during the transition period when dairy cows are more susceptible to metabolic disorders (i.e., hypocalcemia) and infectious diseases (i.e., mastitis) (Hernandez-Castellano et al. 2017; Ingvartsen 2006). Similarly, the use of crops tolerant to droughts or high temperatures (i.e., teff, saltbush, seaweeds) as well as novel by-products (i.e., tomato or banana fruit waste) needs to be investigated with special focus on soil contamination, rumen degradability, ruminal methane production, energy content, and the impact on animal performance and milk quality.

In summary and based on the described above, future research on dairy cattle physiology in the tropics should focus on (1) by-products for animal nutrition in order to save land for human food production, (2) novel and alternative feeds resistant to droughts and high temperatures, (3) methane emissions, (4) heat stress, and (5) metabolic disorders and immune status.

\section{Water buffalo and dairy production: the invisible species}

Water buffaloes (Bubalus bubalis) are the predominant domesticated ruminants in Asia and Mediterranean countries, and it is currently spreading to Africa and South American regions. Buffaloes are divided into two sub-species: swamp buffalo and riverine buffalo, with a diploid chromosome of 48 and 50, respectively (Deb et al. 2016). Swamp buffaloes are mainly raised in Asia, particularly in China, Myanmar, Philippines, Vietnam, Indonesia, Lao PDR, and Thailand, serving as a draft, transportation, and meat, and providing manure and by-products (hide, hoof) (Chantalakhana 1990). Riverine buffaloes are farmed in South Asia, such as India, Pakistan, Nepal, and Bangladesh, and in the Mediterranean, such as Italy, Bulgaria, Romania, or Greece, producing meat and milk products especially mozzarella cheese and yogurt.

Presently, more than $97 \%$ of the world's population of buffaloes is in Asia. Although, there has been a dramatic decrease in buffalo populations in some countries, farm management, breeding, nutrition, and feeding as well as governmental policies have been implemented to promote their development and production.

As described, buffaloes are efficient utilizers of roughages especially the poor-quality forages and agricultural crop residues (Wanapat and Rowlinson 2007; Devendra 2007). Rumen ecology of buffaloes hosting more cellulolytic bacterial population and a higher capability of N-recycling has been additionally reported (Devendra 1985; Wanapat and Rowlinson 2007).

As described above, the world population is expected to increase sharply in the near future. Therefore, the enhancement of buffalo production for both meat and milk is necessary.

Research pertaining to efficient rumen fermentation and rumen microbiomes and aspects of nutrition, physiology, breeding, management, meat and milk processing, and technology, as well as production systems, are necessary for these animals. Modern technology and well-trained animal scientists will contribute to the general knowledge of buffalo production and will ultimately provide more data in the production efficiency scenario.

\section{Small ruminants: the poor man's cow}

Small ruminants, mainly sheep and goats, are key species in the tropics and the subtropics. Indeed, they are found all over these vast regions. Typically, they are not only associated with subsistence farming systems for milk production, but also for meat production in all types of systems. There are however some exceptions, particularly in semi-arid regions, where goat and ewe milk are regularly used in the local population's diets. In such areas, standard bovine milk production is virtually impossible and local cattle breeds produce minimal amounts of milk. In such areas, goats and sheep are particularly well adapted. Improving milk production from small dairy ruminants is a major objective for the next 20 years, and it will require important inputs from animal science. One of the most important challenges in small ruminant dairy production is related to increased milk output. Indeed, most small ruminant breeds have low milk yields, particularly in extensive management systems. Increasing milk production from these species would require a combination of different research areas. For instance, breeding studies should be performed on those breeds that are endemic to temperate climates in order to increase milk production in the tropics, similarly to what was done with the Alpine or the Saanen breeds (Haenlein 1996; Pulina et al. 2018). In addition, tropical sheep and goat breeds 
have a unique adaptation to tropical climates and tropical feed resources. Therefore, novel feed and fodder sources need to be investigated in order to complement extensive pasture-based systems and increased milk production in these regions. This subject has been extensively reviewed (Halmemies-BeauchetFilleau et al. 2018). Examples include for instance the use of cactus (Catunda et al. 2016), among many others.

Seasonal weight loss (SWL) is another important issue in the tropics. Indeed, ruminant production in these regions is heavily dependent on natural pastures. During the dry season, pasture availability and quality decrease significantly and animals may decrease in body weight (BW) by $30 \%$ which has important consequences on animal performance and health. We have demonstrated such effects in West Africa (de Almeida and Cardoso 2008), Southern Africa (Almeida et al. 2006; Almeida et al. 2007), or the Canary Islands (Lérias et al. 2013, 2015). This problem may be solved by the use of supplementation. In general terms, this is however difficult to do in tropical countries due to the high costs and poor infrastructure. It is therefore important to use animals that have a natural ability to cope with seasonal weight loss. Local breeds such as Damara (Almeida 2011) and Barbados Blackbelly (De Almeida 2018) sheep or Majorera dairy goats (Lérias et al. 2013) have adapted over the years to areas with seasonal variation of pastures. Research on the molecular determinants of such traits using proteomics (HernándezCastellano et al. 2016; Cugno et al. 2016; Ferreira et al. 2017; Miller et al. 2019a, b) and metabolomics (Palma et al. 2016a, b, 2017) is bringing novel insights, contributing towards the establishment of novel selection markers of tolerance to seasonal weight loss.

\section{Camelids: desert dairy}

The Arabian camel (Camelus dromedarius) is a unique species that can be a better provider of meat and milk in desert areas compared with other farm animals, which are severely affected by heat stress and scarcity of feed and water. Camels are essential in Saudi Arabia agricultural production systems. Some of the research areas performed in camels are related for instance to the improvement of camel reproduction. Camels are characterized by seasonal reproductive activity. Current research is addressed to shorten focus on the reduction of the calving interval and to improve the reproductive performance of camels through manipulation of the photoperiod using melatonin administration. The use of assisted reproductive techniques has been recently used in camel reproduction such as estrous synchronization, in vitro fertilization, embryo transfer, and cloning. In this way, genetics, genomics, and proteomics have played an essential role in the determination of camel pedigree. Genomics has also been used for the interpretation of the molecular mechanisms controlling camel adaptability to arid and severe harsh environmental conditions. Current research should focus on the use of proteomics to discover new proteins in camel biological fluids such as milk and urine. Immunology in Camels is another interesting research area that is expected to develop in the near future. One clear example is the production of nanobodies in camelids. Nanobodies are special antibodies characterized by the lack of light chains and are exclusively composed by heavy-chain homodimer. Due to the smaller size of these antibodies, they are able to penetrate the typically inaccessible parts of solid tumors with low immunogenicity. Nanobodies are also considered as a significant tool in various therapeutic disciplines due to their unique ability to bind or attach to other proteins and nanoparticles by using noncomplex chemical treatments.

\section{Dairy production systems: major challenges}

In the tropics, there is a high diversity of dairy production systems in terms of feeding management, the scale of production, and dairy animal species and breeds. Milk production in the tropics ranges from grazing systems in large cultivated pastures to small-scale mixed farming systems and pastoralists and agro-pastoralist dairy production systems (Moran 2005). However, there are some continent-specific characteristics. In Latin America, the cattle grazing system is the most important, but in Asia almost 50\% of the milk is produced by buffaloes raised in feeding systems of crop residues and cut-and-carry. In sub-Saharan Africa, $75 \%$ of the milk comes from cattle grazing natural pastures. Milk from dairy cattle represents nearly $100 \%$ of the milk produced in Latin America and Oceania. Interestingly, dairy animals other than cattle (e.g., buffaloes, goats, sheep, and camels) produce respectively $39 \%$ and $26 \%$ of milk production in Asia and Africa (FAO 2018). Despite the economic importance of dairy production systems and their major role for the household security of millions of people, the productivity is low. According to FAOSTAT (2018), 77\% of the total number of dairy cattle in the world are in Africa and Asia and represent 33\% of the world's milk production whereas, in Europe and North America, $21 \%$ of the world's dairy cattle produce $51 \%$ of the world's milk production.

The challenges for the development of the dairy production systems in tropics vary from one production system, one country, or one continent to another but can however be classified into two main challenges intimately linked: the biotechnical (i.e., management of genetics, feed resources, the health, and the reproduction) and the organizational (i.e., functional breeding policy, market organization). Local breeds are however well adapted to such environments but produce generally low milk outputs. However, before the introduction of exotic highly productive breeds, the performances of the existing local breeds should be carefully analyzed. A more pertinent 
strategy, which has been practiced with encouraging results, is crossbreeding with highly productive exotic breeds and/or genetic selection of locally adapted breeds for increased milk production (Baur et al. 2017; Biscarini et al. 2015). The interactions between the management of the feeding systems, the health, and the reproduction (discussed in this editorial) are also important levers to increase milk production (Rangel et al. 2017; Rukkwamsuk 2011; van Houtert and Sykes 1999). However, it will be necessary for the development of national and regional networks involving farmers, veterinaries, and governmental extension agents to transfer technology to the agriculture sector and health and extension services. Furthermore, there is a need for more research on the tropical feeding systems for dairy animals and their interaction with health and reproduction according to the production systems for the development of management practices in close collaboration with extension and training services.

\section{Reproduction and dairy science in the tropics}

Dairy milk production in tropical countries plays an important economic role in the productive chain of smalland medium-scale farmers. However, there are several challenges that these producers must face in order to improve the productive and reproductive efficiency of the herd. One of the most important factors is the nutrition of the dairy cow that inhabits an elevated environmental temperature, solar radiation, and high humidity.

It is well known that tropical pastures are of lower nutritional quality compared with those in developed temperate climates. These pastures contain less leaves, which decreases protein intake and digestible energy, and in turn compromises the performance of the dairy cow, especially in milk production and reproduction efficiency (Ørskov 2005). Therefore, it will be necessary to improve the nutritional value by the incorporation of legumes or high-quality pasture adapted to this environmental condition or supplementation in a specific time of the year to increase milk production and preserve reproductive efficiency.

Tropical dairy cows under thermal stress conditions compromise reproductive efficiency affecting fertilization rate and embryo development with a significant decrease in conception rate (Hansen 2007). Estrous behavior is often compromised during summer, increasing the rate of undetected estrous events up to $80 \%$. Genetic adaptation to heat stress has been studied in different cattle breeds. For instance, the slick hair gene identified in Carora cattle has been introduced in Holsteins cows by crossbreeding (Olson et al. 2003). This resulted in crossbreed dairy cows with lick hair that had lower body temperatures and higher milk production than that of purebred.
Different management strategies can improve reproductive performance of lactating dairy cows under heat stress conditions. Intensive cooling for instance can reduce heat stress that results in increased fertility (Collier et al. 2006).

Finally, the application of some reproductive technologies can compensate the infertility problem during heat stress conditions such as the application of in vivo embryo transfer or the production of in vitro embryos with growth factors that improve fertility (Hansen 2007).

\section{Dairy animal health in the tropics: major concerns}

As with dairy farming in all parts of the world, increased dairy outputs require improved efficiencies, increased agricultural intensification, and associated changes in land use (McMahon et al. 2015). This in turn requires consideration of environmental factors to address increased risk factors for the enhanced evolvement and interaction of bacterial pathogens, including transmission, routes of exposure, detection, management, and prevention. Management solutions require interdisciplinary approaches and review of local bio-system complexity, as disease dynamics are complex, and in response to multiple drivers (Perry et al. 2013). Pandemic bacterial diseases caused by pathogenic species of Brucella, Mycobacterium, and Leptospira continue to dominate dairy producing animals and require education and management to reduce carriage and transmission between animals, as well as minimizing zoonotic risks via direct contact with infected animal tissues, or indirectly via contact with contaminated environs or food products. Modern farming practices are linked to emerging zoonotic disease (Jones et al. 2013). More specifically for dairy producers, bacteria, including Gram-positives (e.g., Staphylococcus, Streptococcus) and Gram-negatives (e.g., Escherichia and Klebsiella), are the predominant cause of clinical mastitis in dairy producing animals which can present as either clinical or subclinical infections (Hernández-Castellano et al. 2017 and Wall et al. 2016). Subclinical infections require enhanced detection methods and implementation of control. Adequate resources are required to educate for awareness of a range of subclinical bacterial infections, their transmission, and zoonotic potential. Adequate resources are required to implement methods of prevention, control, and biosecurity, appropriate for local pastoral settings or semi-intensified systems. The management of dairy animals in the tropics has the added consideration of stress, including heat stress that may act as a significant host risk factor in susceptibility to bacterial infection and transmission. 


\section{Dairy animal health in the tropics: epidemiology and emerging diseases}

Animal health is crucial for the productivity of dairy animals. The spectrum of diseases is however often different in the tropics, for many reasons. While intensive dairy is evolving in many countries, dairy production is still characterized by small-scale farms with low inputs and low outputs, which reduces the risk of many production-related diseases. The low input systems are not only in terms of quantity but may also be in terms of quality. Feed is often containing different byproducts which may be low in nutrients, possibly resulting in nutrient deficiencies in the dairy animals. Both feed and water are limited resources in many settings, and in addition to these, they may be contaminated by both biological and chemical hazards, including mycotoxins, heavy metals, pathogens, and antimicrobials, either intentionally added or in the form of residues, and these contaminants can all contribute to diseases, in addition to the promotion of antimicrobial resistance.

Dairy farms in the tropics also often have a low level of biosecurity, limited possibilities for isolations, and frequently limited training and knowledge about disease prevention, which render them more vulnerable for infectious diseases. In addition, the tropical climate is often beneficial for the transmission of a number of infectious diseases that are not as easily spread in temperate climates, including a number of vectorborne diseases such as the important diseases East Coast fever and Nagana (African animal trypanosomiasis), due to the dependence of the vectors on climate and environment.

It is not only the climate that makes infectious diseases relatively more important in the tropics. Many low- and middle-income countries are also facing difficulties in effective veterinary services, enforcement of legislation, and frequently an unregulated pharmaceutical industry where it may be both easier and more economical for farmers to treat animals themselves than to consult veterinarians, which themselves are likely to have limited possibilities for diagnosis. Limited resources of governments to implement vaccination programs, limited resources of farmers to afford preventive measures, and often limited evidence and knowledge on what to prioritize further complicates the control of infectious diseases. Economic or religious restrictions may prevent culling to reduce the spread of diseases, and often fear of losses may create increased animal sales in the face of disease outbreaks, further exacerbating the problem.

\section{Dairy animal and human health in the tropics}

Milk is an important food. Therefore, dairy production is of great importance for human health, mainly in developing countries where milk production, processing, and selling support incomes of many poor families. In the tropics, milk is especially important for vegetarian populations, such as in India, where specific dairy products are the only source of animal proteins for the population. Despite the positive nutritional aspects of milk consumption, there are several health risks for humans associated with dairy production and consumption. Workers involved in dairy production are at risk of zoonotic and other occupational diseases. For instance, contact with fetal or aborted materials can cause Rift Valley fever virus or brucellosis to these people. In addition, direct contact to urine or feces may increase the risk of suffering leptospirosis, salmonellosis, and cryptosporidiosis. Dairy consumers are also at risk from biological, chemical, and physical hazards, including zoonotic pathogens. Most of the health risks are usually related to biological hazards. Potential diseases for dairy consumers are brucellosis, salmonellosis, coxiellosis, and campylobacteriosis among others. Chemical hazards for dairy consumers include aflatoxins and pesticides. Antibiotics residues are also very important as they contribute to the emergence of antimicrobial resistant pathogens.

Excessive consumption of dairy products, especially products high in sugar such as milk sweets or ice cream, is associated with overweight and obesity, which in turn is associated with a range of diseases. This is an increasing problem in many low- and middle-income countries, and this problem is related to urbanization, raised incomes, and globalization. On the other hand, the increasing problem of allergies and autoimmune disease is reduced by exposure to farms and dairy cattle.

\section{The dairy sector and the environment: emissions, pollution, and sustainability}

Greenhouse gas (GHG) emissions are the main cause of global climate change, namely global warming. A total of $14.5 \%$ of these total GHG emissions was estimated to originate from the livestock sector (Gerber et al. 2013), and the global dairy sector contributes roughly $4.0 \%$ to the total global anthropogenic GHG emissions (FAO 2010). A report from FAO (FAO 2010) provides estimates of GHG emissions associated with milk production and processing for main regions and farming systems of the world. This report stressed the fact that GHG emissions expressed per kilogram of fat- and protein-corrected milk (FPCM) vary significantly between regions with the highest found in sub-Saharan Africa, North Africa, and the Near East with an average of 3.7 to $7.5 \mathrm{~kg} \mathrm{CO} 2$-eq. per kilogram FPCM (FAO 2010). Furthermore, GHG emissions rely also on the production system with higher emissions observed in grazing systems than in mixed systems (FAO 2010). Methane is the main contributor (50\%) to GHG emissions in the dairy sector, followed by nitrous oxide that contributes in $27-38 \%$ depending on the region, and finally carbon dioxide that contributes in 10 to $20 \%$. It is of note that the contribution of $\mathrm{N}_{2} \mathrm{O}$ is higher in developing countries than in developed 
countries, while the opposite occurs regarding $\mathrm{CO}_{2}$ (FAO 2010). The main source of methane in the dairy sector is the enteric fermentation, while $\mathrm{N}_{2} \mathrm{O}$ emissions originate mainly from the application of manure and chemical fertilizers to crops or grassland and from the deposition of manure and urine on pasture crops. Storage and handling of manure can also be a significant source of both $\mathrm{N}_{2} \mathrm{O}$ and $\mathrm{CH}_{4}$.

Dairy production contributes to global warming but dairy is also affected itself by climate changes at different steps of production, with heat stress becoming one of the main limitations with direct impact on milk production and GHG emissions. Given the fact that the demand for livestock products, namely dairy products, will increase over coming years, it is fundamental to support the implementation of technical solutions for mitigation of GHG emissions. Technological options for the mitigation of GHG emissions from livestock were reviewed by Steinfeld et al. (2006) and Reid et al. (2004) who summarize solutions to graze livestock from the tropics.

Relative to $\mathrm{CO}_{2}$ emissions, some solutions were proposed to enhance carbon sequestration in Africa, namely conversion of cropland to grassland and decreasing grazing intensity (Thornton et al. 2009). However, efforts have to be focused on the reduction of methane and nitrous oxide emissions. Indeed, $\mathrm{CH}_{4}$ and $\mathrm{N}_{2} \mathrm{O}$ emissions have a warming potential of 21 and $310 \mathrm{CO}_{2}$-equivalent over a 100 -year time period (UNFCCC 2014). The most obvious solution to reducing methane emissions is to reduce livestock numbers but such a measure will have a strong impact not only on the economy but also on social and cultural sectors. There will be an increase in livestock numbers in sub-Saharan Africa with a potential increase of $40 \%$ of methane emissions from domesticated ruminants until 2030. Several strategies exist to mitigate enteric fermentation, namely an increase of dietary fat content or the use of feed supplements (Rojas-Downing et al. 2017). A decrease of 4-5\% of $\mathrm{CH}_{4}$ emissions can be achieved by increasing $1 \%$ dietary fat (Beauchemin et al. 2008; Martin et al. 2010). The control of $\mathrm{N}_{2} \mathrm{O}$ emissions is more complex even if efficient solutions are proposed to reduce emissions from pasture by using nitrification inhibitors (Ledgard et al. 2014) or by improving manure management (Chadwick et al. 2011).

\section{Conclusions}

Dairy production in the tropics is perhaps one of the most challenging subjects within world agriculture and animal production. Indeed, the challenges presented are immense and include complex and interconnected factors such as heat stress and different physiology of tropical animals, unavailability of high-quality fodders and feedstuffs, unique species such as water buffalo or camel, poorly-studied diseases, and deficient health status and policies. Solving all these problems is a complex task that must involve all the players in the field: scientists, extension officers, policy makers, and of course farmers and consumers. Tropical Animal Health and Production, as the leading journal in animal production specifically dedicated to the tropics, has always dedicated special attention to ruminant production, particularly dairy. Indeed, our journal receives and publishes high-quality research from all over the tropical regions. Many are dedicated to milk and dairy production. With the inauguration of this novel topical collection "Dairy Science and Health in the Tropics," we further reinforce this key area. We hope that our modest contribution will help in such effort.

\section{References}

Almeida, A.M., 2011. The Damara in the context of Southern Africa fattailed sheep breeds. Trop Anim Health Prod 43, 1427-1441.

Almeida, A.M., Schwalbach, L.M., de Waal, H.O., Greyling, J.P. and Cardoso, L.A., 2006. The effect of supplementation on productive performance of Boer goat bucks fed winter veld hay. Trop Anim Health Prod 38, 443-449.

Almeida, A.M., Schwalbach, L.M.J., Cardoso, L.A. and Greyling, J.P.C., 2007. Scrotal, testicular and semen characteristics of young Boer bucks fed winter veld hay: the effect of nutritional supplementation. Small Ruminant Research 73, 216-220.

Baur, I., Tabin, L., Banda, M., Chiumia, D. and Lips, M., 2017, Improving dairy production in Malawi: a literature review. Tropical Animal Health and Production 49, 251-258.

Beauchemin, K.A., Eriksen, L., Norgaard, P. and Rode, L.M., 2008. Nutritional management for enteric methane abatement: a review. Aust J Exp Agric 48, 21-27.

Biscarini, F., Nicolazzi, E.L., Stella, A., Boettcher, P.J. and Gandini, G., 2015, Challenges and opportunities in genetic improvement of local livestock breeds. Frontiers in Genetics 6, 33.

Britt, J.H., Cushman, R.A., Dechow, C.D., Dobson, H., Humblot, P., Hutjens, M.F., Jones, G.A., Ruegg, P.S., Sheldon, I.M. and Stevenson, J.S., 2018. Invited review: Learning from the future-A vision for dairy farms and cows in 2067. Journal of Dairy Science 101, 3722-3741.

Catunda, K.L., de Aguiar, E.M., de Góes Neto, P.E., da Silva, J.G., Moreira, J.A., do Nascimento Rangel, A. H. and de Lima Júnior, D.M., 2016. Gross composition, fatty acid profile and sensory characteristics of Saanen goat milk fed with Cacti varieties. Trop Anim Health Prod 48, 1253-1259.

Chadwick, D., Sommer, S., Thorman, R., Fangueiro, D., Cardenas, L., Amon, B. and Misselbrook, T., 2011. Manure management: Implications for greenhouse gas emissions. Animal Feed Science and Technology 166-167, 514-531.

Chantalakhana, C., 1990. Small farm animal production and sustainable agriculture. In: Proc. The 5th AAAP Animal Science Congress, Taipei, Taiwan. Vol. 2. Taipei, Taiwan.

Collier, R.J. Dahl G.E., VanBaale, M.J. 2006. Major advances associated with environmental effects on dairy cattle. J. Dairy Sci. 89, 1244 1253

Cugno, G., Parreira, J.R., Ferlizza, E., Hernández-Castellano, L.E., Carneiro, M., Renaut, J., Castro, N., Arguello, A., Capote, J., Campos, A.M. and Almeida, A.M., 2016. The Goat (Capra hircus) Mammary Gland Mitochondrial Proteome: A Study on the Effect of 
Weight Loss Using Blue-Native PAGE and Two-Dimensional Gel Electrophoresis. PLoS One. 11:e0151599.

de Almeida, A. M, 2018. Barbados Blackbelly: the Caribbean ovine genetic resource. Trop Anim Health Prod 50, 239-250.

de Almeida, A.M. and Cardoso, L.A., 2008. Animal production and genetic resources in Guinea Bissau: II-Tombali province. Trop Anim Health Prod 40, 537-543.

De Almeida, A.M., 2018. Improving animal production and health in the tropics-the challenge of humankind. Trop Anim Health Prod 50, 1177-1179.

Deb, G.K., Nahar, T.N., Duran, P.G., and Presicce, G.A., 2016. Safe and sustainable traditional production: the water buffalo in Asia. Frontiers in Environmental Science, 4, 38.

Devendra, C., 1985. Comparative nitrogen utilization in Malaysian water Buffalos and Kedah-Kelanton cattle. In Proceedings of the 3rd AAAP Animal Science Congress, Seoul, Korea, 1985 (Vol. 2, pp. 873-875).

Devendra, C., 2007. Perspectives on animal production systems in Asia. Livestock Science 106, 1-18.

FAO, 2018, Gateway to dairy production and products. http://www.fao. org/dairy-production-products/en/

FAO. 2010. Greenhouse gas emissions from the dairy sector - A life cycle assessment. FAO, Rome.

Ferreira, A.M., Grossmann, J., Fortes, C., Kilminster, T., Scanlon, T., Milton, J., Greeff, J., Oldham, C., Nanni, P. and Almeida, A.M., 2017. The sheep (Ovis aries) muscle proteome: Decoding the mechanisms of tolerance to Seasonal Weight Loss using label-free proteomics. J Proteomics 16, 57-67.

Gerber, P.J., Steinfeld, H., Henderson, B., Mottet, A., Opio, C., Dijkman, J., Falcucci, A. and Tempio, G., 2013. Tackling Climate Change Through Livestock: A Global Assessment of Emissions and Mitigation Opportunities. FAO, Rome.

Haenlein, G.F., 1996. Status and prospects of the dairy goat industry in the United States. J Anim Sci 74, 1173-1181.

Halmemies-Beauchet-Filleau, A., Rinne, M., Lamminen, M., Mapato, C., Ampapon, T., Wanapat, M. and Vanhatalo, A., 2018. Review: Alternative and novel feeds for ruminants: nutritive value, product quality and environmental aspects. Animal 12, s295-s309.

Hansen, P.J., 2007. Exploitation of genetic and physiological determinants of embryonic resistance to elevated temperature to improve embryonic survival in dairy cattle during heat stress. Theriogenology 68, 242-249.

Hernandez-Castellano, L., Wall, S. K., Stephan, R., Corti, S., and Bruckmaier, R., 2017. Milk somatic cell count, lactate dehydrogenase activity, and immunoglobulin $\mathrm{G}$ concentration associated with mastitis caused by different pathogens: A field study. Schweiz Arch Tierheilkd 159, 283-290.

Hernández-Castellano, L.E., Ferreira, A.M., Nanni, P., Grossmann, J., Argüello, A., Capote, J., Cai, G., Lippolis, J., Castro, N. and de Almeida, A.M., 2016. The goat (Capra hircus) mammary gland secretory tissue proteome as influenced by weight loss: A study using label free proteomics. J Proteomics 145, 60-69.

Hernández-Castellano, L.E., Hernandez, L.L., Sauerwein, H. and Bruckmaier, R.M., 2017. Endocrine and metabolic changes in transition dairy cows are affected by prepartum infusions of a serotonin precursor. Journal of Dairy Science 100, 5050-5057.

Ingvartsen, K.L., 2006. Feeding- and management-related diseases in the transition cow - Physiological adaptations around calving and strategies to reduce feeding-related diseases. Animal Feed Science and Technology 126, 175-213.

Jones, B.A., Grace, D., Kock, R., Alonso, S., Rushton, J., Said, M.Y., McKeever, D., Mutua, F., Young, J., McDermott, J., 2013. Zoonosis emergence linked to agricultural intensification and environmental change. Proceedings of the National Academy of Sciences 110, 8399-8404.
Ledgard, S.F., Luo, J., Sprosen, M.S., Wyatt, J.B., Balvert, S.F. and Lindsey, S.B., 2014. Effects of the nitrification inhibitor dicyandiamide (DCD) on pasture production, nitrous oxide emissions and nitrate leaching in Waikato, New Zealand, New Zealand Journal of Agricultural Research 57, 294-315.

Lérias, J.R., Hernández-Castellano, L.E., Morales-Delanuez, A., Araújo, S.S., Castro, N., Argüello, A., Capote, J. and de Almeida, A.M., 2013. Body live weight and milk production parameters in the Majorera and Palmera goat breeds from the Canary Islands: influence of weight loss. Trop Anim Health Prod 45, 1731-1736.

Lérias, J.R., Peña, R., Hernández-Castellano, L.E., Capote, J., Castro, N., Argüello, A., Araújo, S.S., Saco, Y., Bassols, A. and Almeida, A.M., 2015. Establishment of the biochemical and endocrine blood profiles in the Majorera and Palmera dairy goat breeds: the effect of feed restriction. J Dairy Res 82, 416-425.

Martin, C., Morgavi, D.P. and Doreau, M., 2010. Methane mitigation in ruminants: from microbe to the farm scale. Animal 4, 351-365.

McMahon, B.J., Wall, P.G., Fanning, S., Fahey, A.G., 2015. Targets to increase food production: One Health implications. Infection ecology \& epidemiology $5,27708$.

Miller, B., Selevsek, N., Grossmann, J., Kilminster, T., Scanlon, T., Daniels, M., Nanni, P., Milton, J., Oldham, C., Greeff, J., Chapwanya, A., Bergfelt, D. and de Almeida, A.M., 2019a. Ovine liver proteome: Assessing mechanisms of seasonal weight loss tolerance between Merino and Damara sheep. J Proteomics 191, 180-190.

Miller, B.A., Chapwanya, A., Kilminster, T., Scanlon, T., Milton, J., Osório, H., Oldham, C., Greeff, J., Bergfelt, D.R., Campos, A.M.O. and Almeida, A.M., 2019b. The ovine hepatic mitochondrial proteome: Understanding seasonal weight loss tolerance in two distinct breeds. PLoS One 14, e0212580.

Moran, J., 2005, Tropical dairy farming. Feeding management for small holder dairy farmers in the humid tropics. FAO, Rome.

Ørskov, E.R., 2005. Silvopastoral systems: technical, environmental and socio-economic challenges. Pastosy Forrajes, 28(1), 5-9.

Olson, T.A., Lucena C., Chase, Jr C.C., Hammond, A.C. 2003. Evidence of a major gene influencing hair length and heat tolerance in Bos Taurus cattle. J. Animal Sci. 81, 80-90.

Palma, M., Alves, S.P., Hernández-Castellano, L.E., Capote, J., Castro, N., Argüello, A., Matzapetakis, M., Bessa, R.J.B. and de Almeida, A.M., 2017. Mammary gland and milk fatty acid composition of two dairy goat breeds under feed-restriction. J Dairy Res 84, 264-271.

Palma, M., Hernández-Castellano, L.E., Castro, N., Arguëllo, A., Capote, J., Matzapetakis, M., and de Almeida, A.M., 2016a. NMRmetabolomics profiling of mammary gland secretory tissue and milk serum in two goat breeds with different levels of tolerance to seasonal weight loss. Mol Biosyst 12, 2094-2107.

Palma, M., Scanlon, T., Kilminster, T., Milton, J., Oldham, C., Greeff, J., Matzapetakis, M. and Almeida, A.M., 2016b. The hepatic and skeletal muscle ovine metabolomes as affected by weight loss: a study in three sheep breeds using NMR-metabolomics. Sci Rep 6, 39120.

Perry, B.D., Grace, D. and Sones, K., 2013. Current drivers and future directions of global livestock disease dynamics. Proceedings of the National Academy of Sciences 110, 20871-20877.

Pulina, G., Milán, M.J., Lavín, M.P., Theodoridis, A., Morin, E., Capote, J., Thomas, D.L., Francesconi, A.H.D. and Caja, G., 2018. Invited review: Current production trends, farm structures, and economics of the dairy sheep and goat sectors. J Dairy Sci 101, 6715-6729.

Rangel, J., Espinosa, J.A., de Pablos-Heredero, C., Barba, C., Velez, A., Rivas, J. and Garcia, A., 2017. Adoption of Innovations and Organizational Practices in Management, Animal Feeding and Reproduction in Dual-Purpose Bovine of Small Farms in Mexico. Revista Cientifica-Facultad De Ciencias Veterinarias 27, 44-55.

Reid, R.S., Thornton, P.K., McCrabb, G.J., Kruska, R.L., Atieno, F. and Jones, P.G., 2004. Is it possible to mitigate greenhouse gas emissions in pastoral ecosystems of the tropics? Environment, Development and Sustainability 6,91-109. 
Rojas-Downing, M.M., Nejadhashemi, A.P., Harrigan, T. and Woznicki, S.A., 2017. Climate change and livestock: impacts, adaptation, and mitigation. Clim. Risk Manag. 16, 145-163.

Rukkwamsuk, T., 2011, Effect of Nutrition on Reproductive Performance of Postparturient Dairy Cows in the Tropics: A Review. Thai J. Vet. Med. 41, 103-107.

Steinfeld, H., Gerber, P., Wassenaar, T., Castel, V., Rosales, M. and de Haan, C., 2006. Livestock's Long Shadow: Environmental Issues and Options. FAO, Rome.

Thornton, P.K., Van de Steeg, J., Notenbaert, A. and Herrrero, M., 2009. The impacts of climate change on livestock and livestock systems in developing countries: A review of what we know and what we need to know. Agric. Syst. 101, 113-127.

UNFCCC (United Nations Framework Convention on Climate Change), 2014. Global Warming Potentials. http://unfccc.int/ghg data/items/ 3825.php. van Houtert, M.F.J. and Sykes, A.R., 1999, Enhancing the profitability of pasture-based dairy production in the humid tropics through improved nutrition. Preventive Veterinary Medicine 38, 147-157.

Wall, S. K., Wellnitz, O., Hernandez-Castellano, L. E., Ahmadpour, A., and Bruckmaier, R. M., 2016. Supraphysiological oxytocin increases the transfer of immunoglobulins and other blood components to milk during lipopolysaccharide- and lipoteichoic acidinduced mastitis in dairy cows. J Dairy Sci 99, 9165-9173.

Wanapat, M., and Rowlinson, P., 2007. Nutrition and feeding of swamp buffalo: feed resources and rumen approach. Italian Journal of Animal Science, 6(Sup2), 67-73.

Publisher's note Springer Nature remains neutral with regard to jurisdictional claims in published maps and institutional affiliations. 